\title{
Circulatory Effects of Stimulating the Carotid Arterial Stretch Receptors in Man at Rest and during Exercise
}

\author{
B. Sture Bevegård, † ANd John T. Shepherd $\ddagger$ \\ (From the Section of Physiology, Mayo Clinic and Mayo Foundation, Rochester, Minn.)
}

Since the demonstration by Hering in 1924 (1) of the baroreceptor function of the carotid sinus, the cardiovascular effects of changes in carotid sinus pressure have been extensively studied in anesthetized animals (2).

In 1957 Ernsting and Parry (3) stimulated the carotid arterial stretch receptors in man by decreasing pressures as much as $80 \mathrm{~mm} \mathrm{Hg}$ below ambient in a box enclosing the neck. In resting subjects, stimulation of these receptors, which include the carotid sinus, caused transient bradycardia, sustained decrease in arterial blood pressure, and decrease in blood flow in the forearm, hand, and calf. The cardiac output was measured on two occasions by the direct Fick method, and it showed no significant difference between the resting value and that obtained when the pressure around the neck was reduced.

In the present study, the technic described by Ernsting and Parry ( 3 ) has been used to add to the information available on the effect of carotid sinus stimulation in man. Observations have been made on normal subjects at rest and during the performance of supine leg exercise.

\section{Methods}

Six healthy subjects, five men and one woman, were studied. They were nonathletic subjects, 22 to 35 years old, performing ordinary physical activity. They had all been previously trained to perform the required leg exercise with completely relaxed arms and were familiar with the experimental procedure and accustomed to the effect of subatmospheric pressures applied to the neck.

The carotid arterial stretch receptors were stimulated by a method described by Ernsting and Parry (3), with plexiglass box enclosing the neck. The thoracic aper-

* Submitted for publication April 8, 1965; accepted October 13, 1965.

This investigation was supported in part by research grant HE- 05883 from the National Institutes of Health.

+ Present address: Stockholm, Sweden.

$\$$ Address requests for reprints to Dr. John T. Shepherd, Mayo Clinic, Rochester, Minn. 55902. ture was sealed airtight by foam rubber lining and a rubber gasket. The box extended cranially to a plane through the anterior alveolar process of the mandible and dorsally through a point just below the ear lobes. The head aperture of the box was closed by a lid, made in two halves, each contoured on the inner side to fit the head of the subject. A layer of foam rubber was attached to the inner rim. Airtight sealing was ensured by maintaining the two halves of the lid under slight pressure against the head of the subject and applying high-vacuum grease between the lid and the upper aspect of the box. The anterior surface of the box was equipped with three wide-bore connections: one to a high-capacity vacuum source, the second to a manometer for direct reading of the vacuum and to a strain-gauge manometer for monitoring of the vacuum, and the third to a valve for manual control of the vacuum in the box by means of an adjustable leak. The onset and offset of neck suction were done almost as a square wave. The time to reach desired pressure was about 1 second. In intervals between observations, the lid of the box was opened.

Heart rate was determined from the electrocardiogram with chest leads.

Radial arterial pressure was measured through a nylon catheter of $1 \mathrm{~mm}$ o.d. connected to a Statham model $\mathrm{P} 23 \mathrm{De}$ strain-gauge transducer. Mean pressure was obtained by electric integration; mid-chest was taken as the reference level.

The reaction of the forearm resistance vessels was estimated from changes in forearm blood flow and radial arterial mean pressure. Forearm blood flow was measured by a strain-gauge plethysmograph compensated for temperature variations (4). The strands were made of silicone rubber tubing of $0.4 \mathrm{~mm}$ i.d. and $0.8 \mathrm{~mm}$ o.d. The gauge was applied to the forearm close to its maximal circumference and at a tension of $10 \mathrm{~g}$; this was adequate to keep it in position without causing detectable congestion. The gauge was calibrated on the forearm at the end of each experiment. For measurement of forearm blood flow, the hand circulation was occluded by a pneumatic cuff around the wrist inflated to $220 \mathrm{~mm} \mathrm{Hg}$ for 1 minute (5) before inflation of the venous collecting cuff. The venous collecting cuff was placed just above the elbow and inflated to $50 \mathrm{~mm} \mathrm{Hg}$ for 15 seconds three times per minute for blood flow determinations. Forearm vascular resistance was expressed as the ratio between radial arterial mean pressure in millimeters $\mathrm{Hg}$ and forearm blood flow in milliliters per minute per $100 \mathrm{ml}$.

To estimate the reaction of the forearm capacity vessels, a pneumatic cuff was wrapped around the arm just 
above the elbow and inflated to a pressure sufficient to occlude the arterial inflow $(300 \mathrm{~mm} \mathrm{Hg}$ usually was applied). The pressure was recorded in a large antecubital vein distal to the cuff via a Teflon catheter and a Statham model P23BB strain-gauge transducer. When the venous pressure had stabilized after arrest of the circulation (usually in 2 minutes), subsequent alterations in pressure were taken to indicate active changes in venous tension mediated by the sympathetic nerves $(6,7)$.

Leg exercise in the supine position was performed with an electrically braked bicycle ergometer attached to the table. The subjects were kept in a fixed position on the table by means of a shoulder support and a saddle. With previous training and this system of fixation to the table, the subjects could perform leg exercise of an intensity corresponding to an oxygen uptake of about $2 \mathrm{~L}$ per minute with the forearms so relaxed and free from passive movements that no serious artifacts were introduced on the records of changes in forearm circumference.

Cardiac output was determined by the dye dilution technic. The indicator dye, indocyanine green, was injected rapidly from a calibrated syringe through a cardiac catheter into the superior vena cava at the entrance to the right atrium. Blood was sampled continuously from a catheter in the radial artery through a cuvette densitometer (8) at a rate of $24 \mathrm{ml}$ per minute by means of a motor-driven syringe. Cardiac output was calculated according to the Stewart-Hamilton equation.

Procedure. The subjects lay supine on a couch in a room at a temperature of about $22^{\circ} \mathrm{C}$, with the elbows extending out from the sides at the level of the third or fourth intercostal space. The proximal forearm segment was about $10 \mathrm{~cm}$ above the anterior chest wall, and the forearm was slightly flexed and inclined at $45^{\circ}$ to the horizontal. The forearm was supported in this position by a small rubber pad under the medial epicondyle and a padded bar against which the upper end of the olecranon process rested. A padded clamp supported the wrist, and the hand rested on a padded bar. We studied the effect of reducing the pressure around the neck to $20,40,50$, and $60 \mathrm{~mm} \mathrm{Hg}$ below ambient pressure for 2 minutes on heart rate, radial arterial blood pressure, blood flow through one forearm, and venous tone in the opposite forearm. Supine leg exercise for 5 minutes at work intensities of 270,540 , and $810 \mathrm{~kg}-\mathrm{m}$ per minute was then performed. During this period the same parameters were studied. A pressure of $50 \mathrm{~mm} \mathrm{Hg}$ below ambient was applied during the fourth minute of each exercise.

After a few days' interval, five of these six subjects were studied again in the supine position. Cardiac output was determined during the application of subatmospheric pressures of 20,40 , and $60 \mathrm{~mm} \mathrm{Hg}$ for 2 minutes to the neck. Control determinations were made before, between, and after those applications. The subjects then performed leg exercise for 6 minutes at three successive loads, separated by resting periods of 10 minutes. The work loads performed were 270,540 , and $810 \mathrm{~kg}-\mathrm{m}$ per minute. During exercise, cardiac output was determined on each load between the third and the fourth minute, between the fourth and the fifth minute when a subatmospheric pressure of $50 \mathrm{~mm} \mathrm{Hg}$ was applied to the neck, and between the fifth and the sixth minute. Thus, at rest and during exercise, the cardiac output determination during neck suction was surrounded by two control determinations. Heart rate was measured continuously, and radial arterial and superior vena caval pressures were measured in the interval between dye injections. Total peripheral resistance was expressed as the ratio of mean arterial pressure (millimeters $\mathrm{Hg}$ ) to cardiac output (liters per minute).

Current methods have been used in the statistical analysis of the data (9). The differences between the average of the data obtained during control determinations and

TABLE I

Effect (mean \pm standard error) of carotid sinus stimulation at rest on some circulatory parameters

\begin{tabular}{|c|c|c|c|c|c|c|}
\hline Rest & Heart rate & $\begin{array}{l}\text { Arterial mean } \\
\text { pressure }\end{array}$ & $\begin{array}{l}\text { Forearm blood } \\
\text { flow }\end{array}$ & $\begin{array}{c}\text { Forearm } \\
\text { vascular } \\
\text { resistance }\end{array}$ & $\begin{array}{l}\text { Cardiac } \\
\text { output }\end{array}$ & $\begin{array}{l}\text { Stroke } \\
\text { volume }\end{array}$ \\
\hline $\begin{array}{l}\text { Control } \\
-20 \mathrm{~mm} \mathrm{Hg} \text { suction } \\
\text { Difference } \\
\text { Observations } \\
\mathrm{p}\end{array}$ & $\begin{array}{c}\text { beats } / \min \\
67.6 \pm 1.9 \\
63.4 \pm 1.3 \\
4.2 \pm 0.8 \\
6 \\
<0.01\end{array}$ & $\begin{array}{c}m m \mathrm{Hg} \\
88.0 \pm 3.1 \\
79.9 \pm 3.1 \\
8.1 \pm 0.8 \\
6 \\
<0.001\end{array}$ & $\begin{array}{c}\mathrm{ml} / \mathrm{min} / 100 \mathrm{ml} \\
4.53 \pm 0.71 \\
4.67 \pm 0.67 \\
-0.14 \pm 0.22 \\
6 \\
>0.9\end{array}$ & $\begin{array}{c}U \\
22.9 \pm 4.2 \\
19.8 \pm 2.7 \\
3.1 \pm 1.6 \\
6 \\
>0.1\end{array}$ & $\begin{array}{c}L / \min \\
6.37 \pm 0.21 \\
5.86 \pm 0.35 \\
0.51 \pm 0.18 \\
\quad<5 \\
<0.05\end{array}$ & $\begin{array}{c}m l \\
101 \pm 4 \\
98 \pm 6 \\
3 \pm 2 \\
5 \\
>0.1\end{array}$ \\
\hline $\begin{array}{l}\text { Control } \\
-40 \mathrm{~mm} \mathrm{Hg} \text { suction } \\
\text { Difference } \\
\text { Observations } \\
\mathrm{p}\end{array}$ & $\begin{array}{c}68.9 \pm 2.1 \\
60.2 \pm 1.4 \\
8.7 \pm 1.1 \\
6 \\
<0.001\end{array}$ & $\begin{array}{c}88.9 \pm 2.7 \\
73.0 \pm 2.7 \\
15.9 \pm 0.5 \\
6 \\
<0.001\end{array}$ & $\begin{array}{r}4.35 \pm 0.52 \\
4.48 \pm 0.47 \\
-0.13 \pm 0.21 \\
6 \\
>0.5\end{array}$ & $\begin{array}{c}22.7 \pm 3.2 \\
18.2 \pm 2.0 \\
4.5 \pm 2.2 \\
6 \\
>0.05\end{array}$ & $\begin{array}{c}5.84 \pm 0.33 \\
5.20 \pm 0.38 \\
0.64 \pm 0.51 \\
5 \\
>0.2\end{array}$ & $\begin{array}{c}94 \pm 5 \\
94 \pm 7 \\
0 \pm 8 \\
5 \\
>0.9\end{array}$ \\
\hline $\begin{array}{l}\text { Control } \\
-60 \mathrm{~mm} \mathrm{Hg} \text { suction } \\
\text { Difference } \\
\text { Observations } \\
\text { p }\end{array}$ & $\begin{array}{c}69.4 \pm 2.1 \\
56.6 \pm 1.2 \\
12.8 \pm 1.1 \\
6 \\
<0.001\end{array}$ & $\begin{array}{c}90.9 \pm 3.1 \\
68.9 \pm 2.4 \\
22.0 \pm 2.5 \\
6 \\
<0.001\end{array}$ & $\begin{array}{r}4.50 \pm 0.50 \\
4.75 \pm 0.75 \\
-0.25 \pm 0.42 \\
6 \\
>0.5\end{array}$ & $\begin{array}{c}23.0 \pm 2.7 \\
17.0 \pm 1.6 \\
6.0 \pm 1.8 \\
6 \\
<0.02\end{array}$ & $\begin{array}{c}5.89 \pm 0.42 \\
5.15 \pm 0.29 \\
0.74 \pm 0.33 \\
5 \\
>0.05\end{array}$ & $\begin{array}{r}96 \pm 7 \\
97 \pm 6 \\
-1 \pm 5 \\
5 \\
>0.8\end{array}$ \\
\hline
\end{tabular}




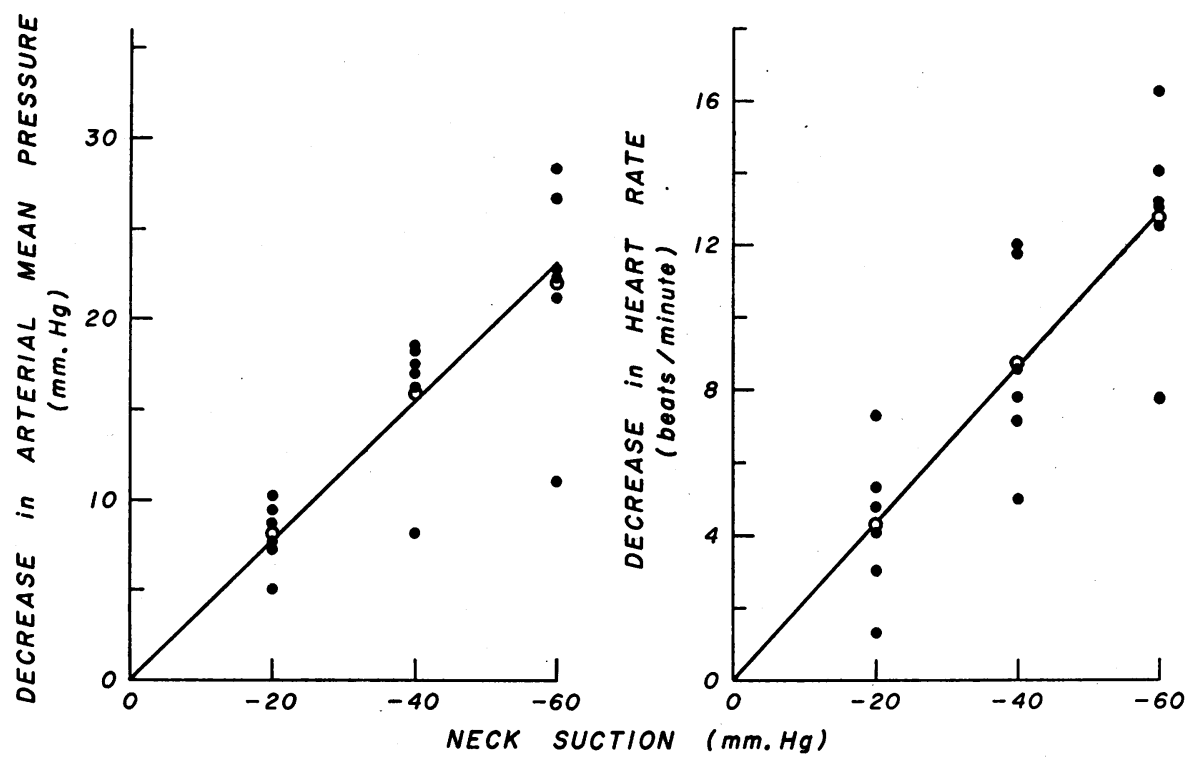

Fig. 1. EFfect of GRAded NeCK SUCTION ON MEAN SYSTEMiC ARTERIAL PRESSURE (LefT PANEL) AND HEART RATE (RIGHT PANEL) IN SIX NORMAL RESTING SUBJECTS. The straight line connects average values (open circles).

the data obtained during neck suction for each subject have been analyzed by a $t$ test for each level of stimulation. For some parameters such as cardiac output and forearm blood flow the possible effect of neck suction was small and close to the reproducibility of available methods. When no significant difference in response between the three levels of stimulation could be demonstrated, a $t$ test was performed on the differences obtained from the total number of observations.

\section{Results}

Effect of carotid sinus stimulation on the resting supine subject

Table I gives the average values with the standard errors of the mean for the parameters measured during the control periods and the periods of neck suction.

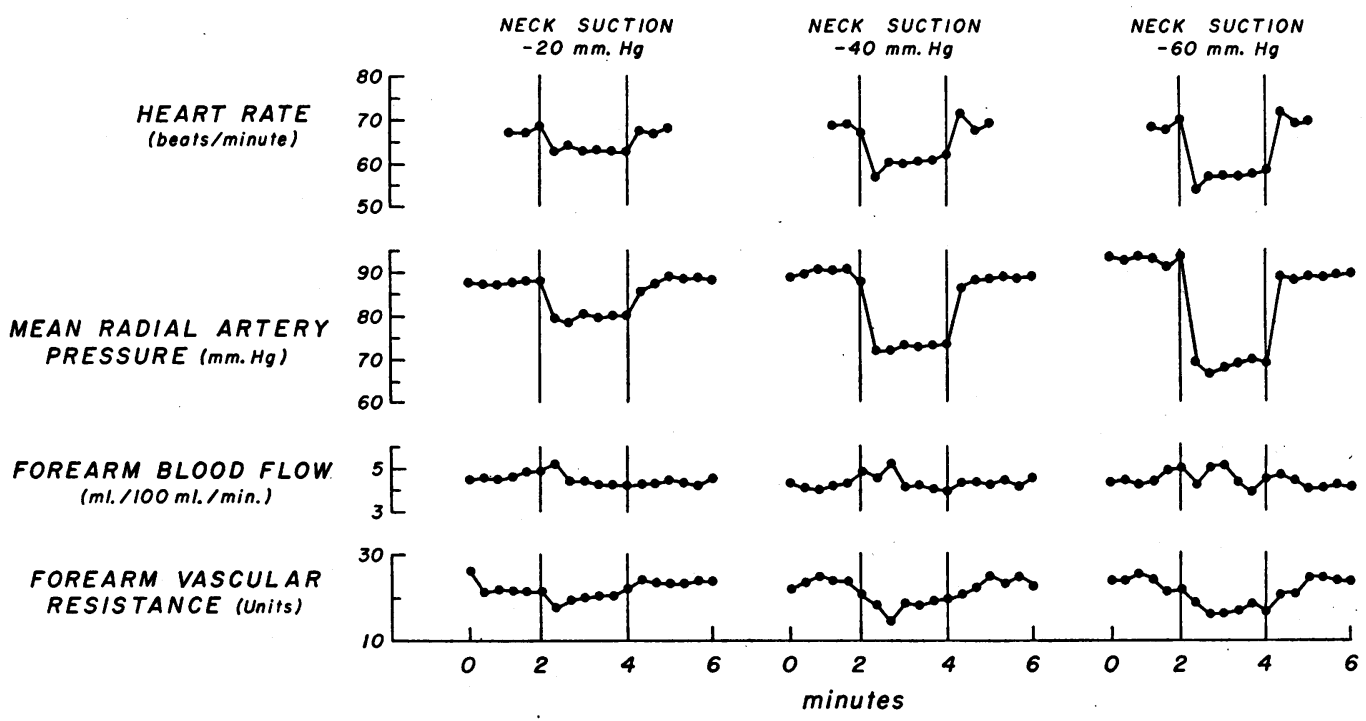

Fig. 2. EFFECTS OF 2-MINUTE PERIODS OF GRAdED NECK SUCTION ON HEART RATE, MEAN RAdial ARTERIAL PRESSURE, FOREARM BLOOD FLOW, AND FOREARM VASCULAR RESISTANCE. Average of six normal resting subjects. 


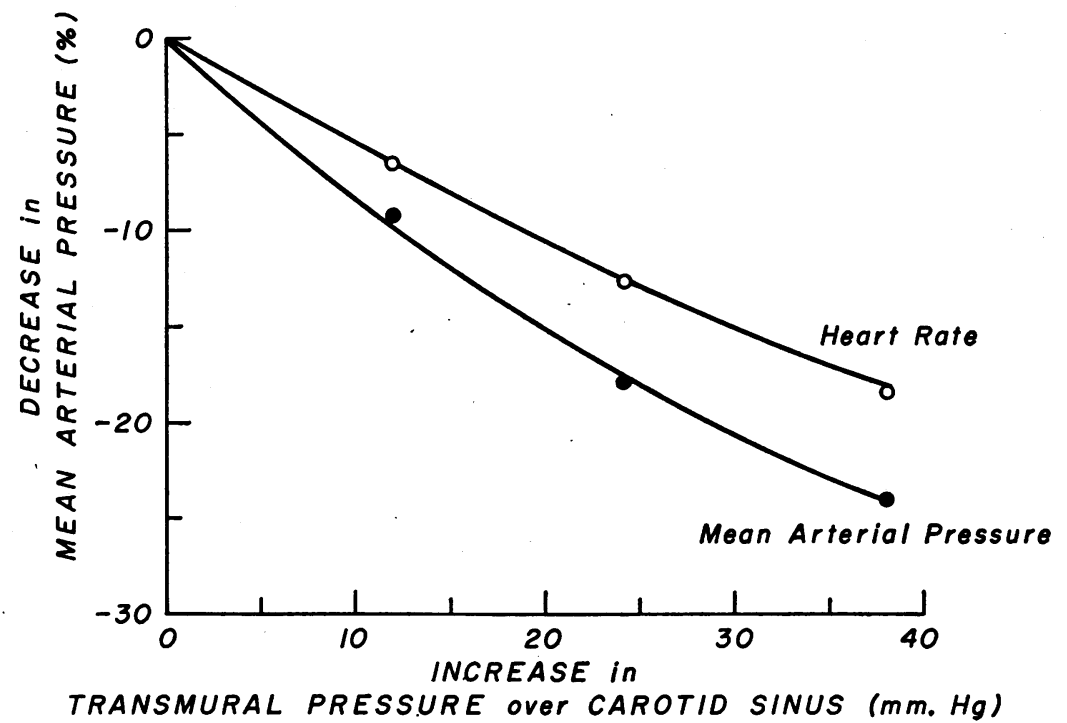

Fig. 3. Percentage changes of mean arterial pressure and heart rate AS FUNCTIONS OF INCREASING "TRANSMURAL PRESSURE" OVER THE CAROTID SINUS. Average of six normal resting subjects.

Heart rate and blood pressure. Reduction of larger ( $\mathrm{p}<0.01$ to 0.001 ) with increasing intenthe pressure around the neck caused sustained decreases in systemic arterial blood pressure and heart. rate. These decreases were significantly sity of stimulation. The blood pressure usually reached a stable level by 10 to 20 seconds after the stimulus had been applied. When the decrease in

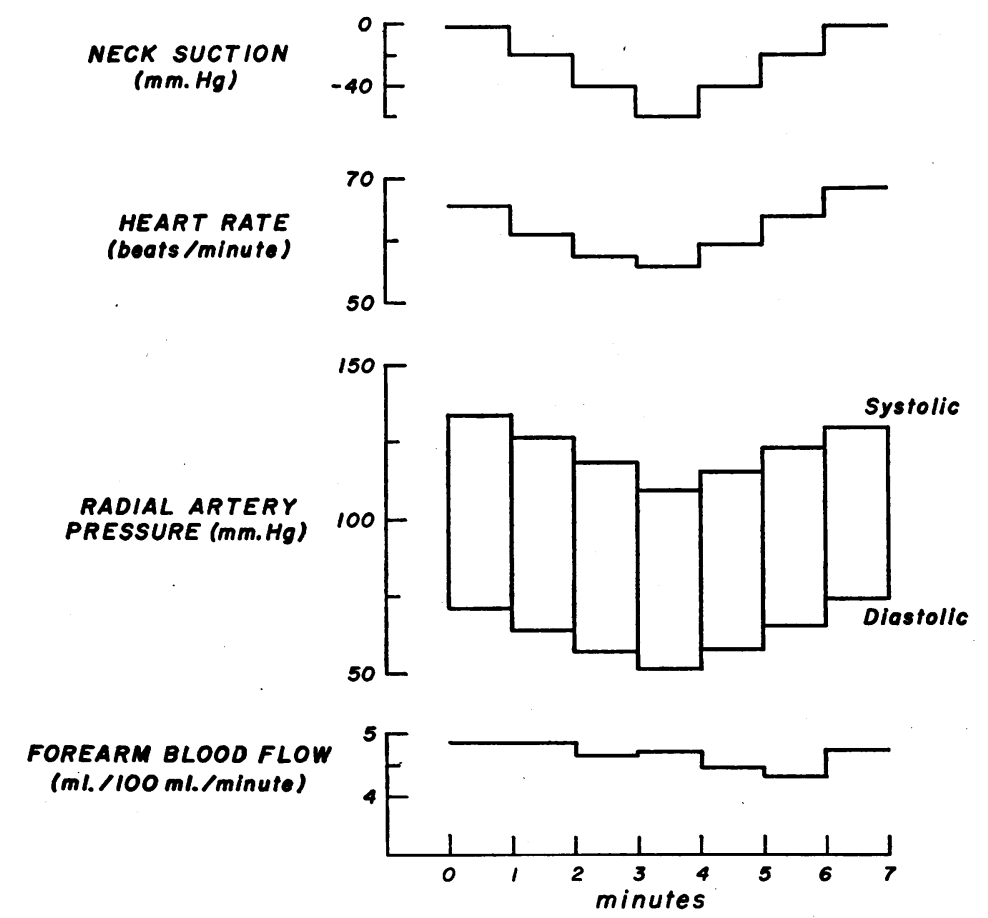

Fig. 4. EFFECT OF STEPWISE ALTERATIONS OF THE DEGREE OF NECK SUCTION ON HEART RATE, RADIAL ARTERIAL PRESSURE, AND FOREARM BLOOD FLow. Average of six normal resting subjects. 
arterial mean pressure was plotted against the intensity of neck suction, an approximately linear relationship was obtained (Figure 1 ). The scatter in the Figure is mainly due to individual variations in sensitivity to the stimulus. The slowing of the heart could be detected by the second beat after application of the stimulus. There was usually: a slight undershoot in heart rate at the onset of neck suction before a stable level was reached and a transient overshoot on release of the stimulus (Figure 2). The heart rate, like the blood pressure, declined on the average in an approximately linear manner with increasing strength of stimulus (Figure 1). If it is assumed that the applied vacuum is completely transmitted to the wall of the carotid artery, then the pressure inside the artery minus the surrounding pressure represents the transmural pressure. When the percentage change in heart rate and blood pressure is expressed as a function of the change in transmural pressure calculated in this way, the relationships shown in Figure 3 are obtained. Over this range of increase in transmural pressure, the heart rate and blood pressure decrease in a slightly curvilinear manner, and the percentage decrease is less for heart rate than for blood pressure $(p<0.02$ for each intensity of suction).

When the degree of neck suction was varied in steps from ambient pressure to $60 \mathrm{~mm} \mathrm{Hg}$ below ambient and back to ambient pressure, heart rate and systolic and diastolic arterial pressures closely followed as step functions (Figure 4). On return from $60 \mathrm{~mm} \mathrm{Hg}$ below ambient to ambient pressure, heart rate, on the average, was higher by 2 to 3 beats per minute than when suction was increased in the same steps. The systolic blood pressure, however, was a few millimeters $\mathrm{Hg}$ lower during the stepwise decrease in suction as compared to the increase. Therefore, the pulse pressure was slightly reduced at this time. Forearm blood flow showed little change, but on the average tended to decrease slightly during the suction period.

Resistance and capacitance vessels. Forearm blood flow was not significantly changed during the periods of neck suction (Table I). Since the mean arterial pressure decreased markedly, the calculated forearm vascular resistance also decreased during the suction periods (Figure 2). This decrease was significant at $60 \mathrm{~mm} \mathrm{Hg}$ below ambient pressure. Although forearm vascular resistance on the average decreased more with increasing intensity of stimulation, there was no significant difference in response between the three levels of stimulation. The decrease in forearm vascular resistance calculated from the total number of observations was significant $(\mathrm{p}<0.001)$. Thus, an increased transmural pressure at the

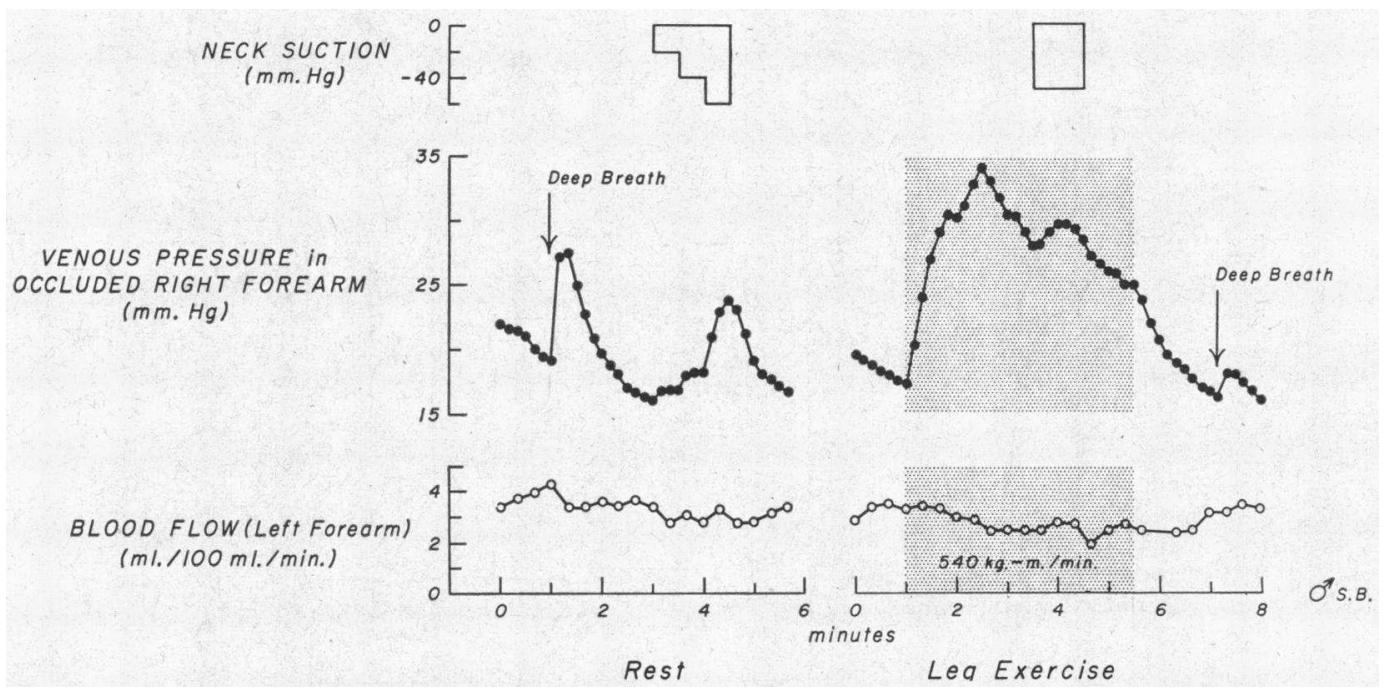

Fig. 5. EFFECT OF NECK SUCTION AT VARIOUS SUBATMOSPHERIC LEVELS AT REST AND DURING EXERCISE ON VENOUS PRESSURE IN A FOREARM WITH ARRESTED CIRCULATION AND ON BLOOD FLOW IN THE OPPOSITE FOREARM. For comparison, the effect of a deep breath is shown. Note the marked sustained increase in venous pressure caused by exercise and the modest increase caused by carotid sinus stimulation during the neck suction. 
TABLE II

Effect (mean \pm standard error) of carotid sinus stimulation during graded supine leg exercise on some circulatory parameters

\begin{tabular}{|c|c|c|c|c|c|c|}
\hline Exercise & Heart rate & $\begin{array}{l}\text { Arterial mean } \\
\text { pressure }\end{array}$ & $\begin{array}{c}\text { Forearm blood } \\
\text { flow }\end{array}$ & $\begin{array}{c}\text { Forearm } \\
\text { vascular } \\
\text { resistance }\end{array}$ & $\begin{array}{l}\text { Cardiac } \\
\text { output }\end{array}$ & $\begin{array}{c}\text { Stroke } \\
\text { volume }\end{array}$ \\
\hline $\begin{array}{l}270 \mathrm{~kg}-\mathrm{m} / \mathrm{min} \\
-50 \mathrm{~mm} \mathrm{Hg} \text { suction } \\
\text { Difference } \\
\text { Observations } \\
\mathrm{p}\end{array}$ & $\begin{array}{c}\text { beats } / \min \\
97.2 \pm 4.0 \\
89.7 \pm 4.6 \\
7.5 \pm 0.7 \\
6 \\
<0.001\end{array}$ & $\begin{array}{c}m m \mathrm{Hg} \\
99.8 \pm 4.1 \\
84.2 \pm 2.2 \\
15.6 \pm 2.8 \\
6 \\
<0.01\end{array}$ & $\begin{array}{c}\mathrm{ml} / \mathrm{min} / 100 \mathrm{ml} \\
4.47 \pm 0.92 \\
4.78 \pm 0.78 \\
-0.31 \pm 0.34 \\
6 \\
>0.4\end{array}$ & $\begin{array}{c}U \\
28.1 \pm 4.8 \\
21.1 \pm 3.3 \\
7.0 \pm 1.8 \\
6 \\
<0.02\end{array}$ & $\begin{array}{c}L / \min \\
10.32 \pm 0.42 \\
9.08 \pm 0.50 \\
1.24 \pm 0.31 \\
5 \\
<0.02\end{array}$ & $\begin{array}{c}m l \\
113 \pm \\
111 \pm \\
2 \pm \\
\begin{array}{c}5 \\
5 \\
>0.6\end{array}\end{array}$ \\
\hline $\begin{array}{l}540 \mathrm{~kg}-\mathrm{m} / \mathrm{min} \\
-50 \mathrm{~mm} \mathrm{Hg} \text { suction } \\
\text { Difference } \\
\text { Observations } \\
\mathrm{p}\end{array}$ & $\begin{array}{c}113.7 \pm 4.3 \\
105.0 \pm 5.4 \\
8.7 \pm 1.2 \\
6 \\
<0.001\end{array}$ & $\begin{array}{c}105.0 \pm 3.5 \\
88.7 \pm 2.9 \\
16.3 \pm 2.4 \\
6 \\
<0.01\end{array}$ & $\begin{array}{r}4.17 \pm 0.66 \\
5.18 \pm 0.85 \\
-1.01 \pm 0.51 \\
6 \\
>0.05\end{array}$ & $\begin{array}{c}29.5 \pm 4.2 \\
20.7 \pm 3.5 \\
8.8 \pm 1.9 \\
6 \\
<0.01\end{array}$ & $\begin{array}{c}14.34 \pm 0.80 \\
11.80 \pm 0.99 \\
2.54 \pm 0.63 \\
5 \\
<0.02\end{array}$ & $\begin{aligned} & 131 \pm 9 \\
& 117 \pm 12 \\
& 14 \pm 7 \\
& 5 \\
&>0.05\end{aligned}$ \\
\hline $\begin{array}{l}810 \mathrm{~kg}-\mathrm{m} / \mathrm{min} \\
-50 \mathrm{~mm} \mathrm{Hg} \text { suction } \\
\text { Difference } \\
\text { Observations } \\
\mathrm{p}\end{array}$ & $\begin{array}{c}130.6 \pm 3.7 \\
124.6 \pm 4.1 \\
6.0 \pm 1.7 \\
5 \\
<0.05\end{array}$ & $\begin{array}{c}110.4 \pm 2.2 \\
95.0 \pm 1.2 \\
15.4 \pm 1.1 \\
5 \\
<0.001\end{array}$ & $\begin{array}{r}4.39 \pm 0.89 \\
5.43 \pm 0.77 \\
-1.04 \pm 0.70 \\
5 \\
>0.2\end{array}$ & $\begin{array}{c}29.5 \pm 4.0 \\
20.2 \pm 4.3 \\
9.3 \pm 4.3 \\
5 \\
>0.05\end{array}$ & $\begin{array}{c}16.16 \pm 1.18 \\
15.06 \pm 1.25 \\
1.10 \pm 1.19 \\
5 \\
>0.4\end{array}$ & $\begin{aligned} & 117 \pm 9 \\
& 113 \pm 10 \\
& 4 \pm 10 \\
& 5 \\
&>0.7\end{aligned}$ \\
\hline
\end{tabular}

carotid sinus caused a dilatation of the resistance vessels in the forearm.

In each subject the reaction of the forearm capacity vessels was estimated from changes in pressure in the forearm veins after the forearm circulation had been completely arrested. In all subjects the venous pressure was either unchanged or increased slightly (Figure 5). Thus there was no indication of any venodilatation in the forearm during neck suction; indeed in some instances, the results indicate that a slight venoconstriction can be elicited with this stimulus.

Cardiac output and stroke volume. Cardiac output decreased in 11 of 15 determinations at rest. The average decrease was $0.6 \mathrm{~L}$ per minute or $10 \%$, and there was no significant difference in response among the three levels of stimulation. Calculated from the total number of observations, the decrease was significant $(p<0.01)$. The stroke volume showed a variable response, but was not significantly changed on the average. The calculated total peripheral vascular resistance was not significantly changed during the period of neck suction. The effects of heart rate and blood pressure were similar to those obtained on the previous test in the same subjects.

\section{Effect of carotid sinus stimulation during graded leg exercise in the supine position}

Table II shows the average values with their standard errors of the mean for the parameters measured during the control periods and the periods of neck suction.

Heart rate and blood pressure. During exercise a 1-minute period of neck suction $(50 \mathrm{~mm} \mathrm{Hg}$ below ambient pressure) caused significant (Table II) and sustained reductions in heart rate and mean arterial pressure (Figure 6). The magnitude of these reductions was not related to the initial levels of heart rate and blood pressure (Figure 7). However, data on more subjects will be required to assess the effects of carotid sinus stimulation on heart rate when the latter exceeds 120 beats per minute, since in one subject the reduction in heart rate was less at rates above 120 beats per minute than at rest.

Resistance and capacity vessels. Forearm blood flow, which during leg exercise of the intensities used in this study remained close to the values present with the subject at rest, on the average increased slightly during the period of neck suction. Since the arterial mean pressure decreased markedly, the calculated forearm vascular resistance was reduced (Figure 6 ). The reduction was significant with the first two work loads. Although, on the average, the reduction in forearm vascular resistance during neck suction was more marked with increasing work intensity, there was no significant difference in response among the three work loads. Calculated from the total number of observations, the reduction in forearm vascular resistance was highly significant $(p<0.001)$, indi- 


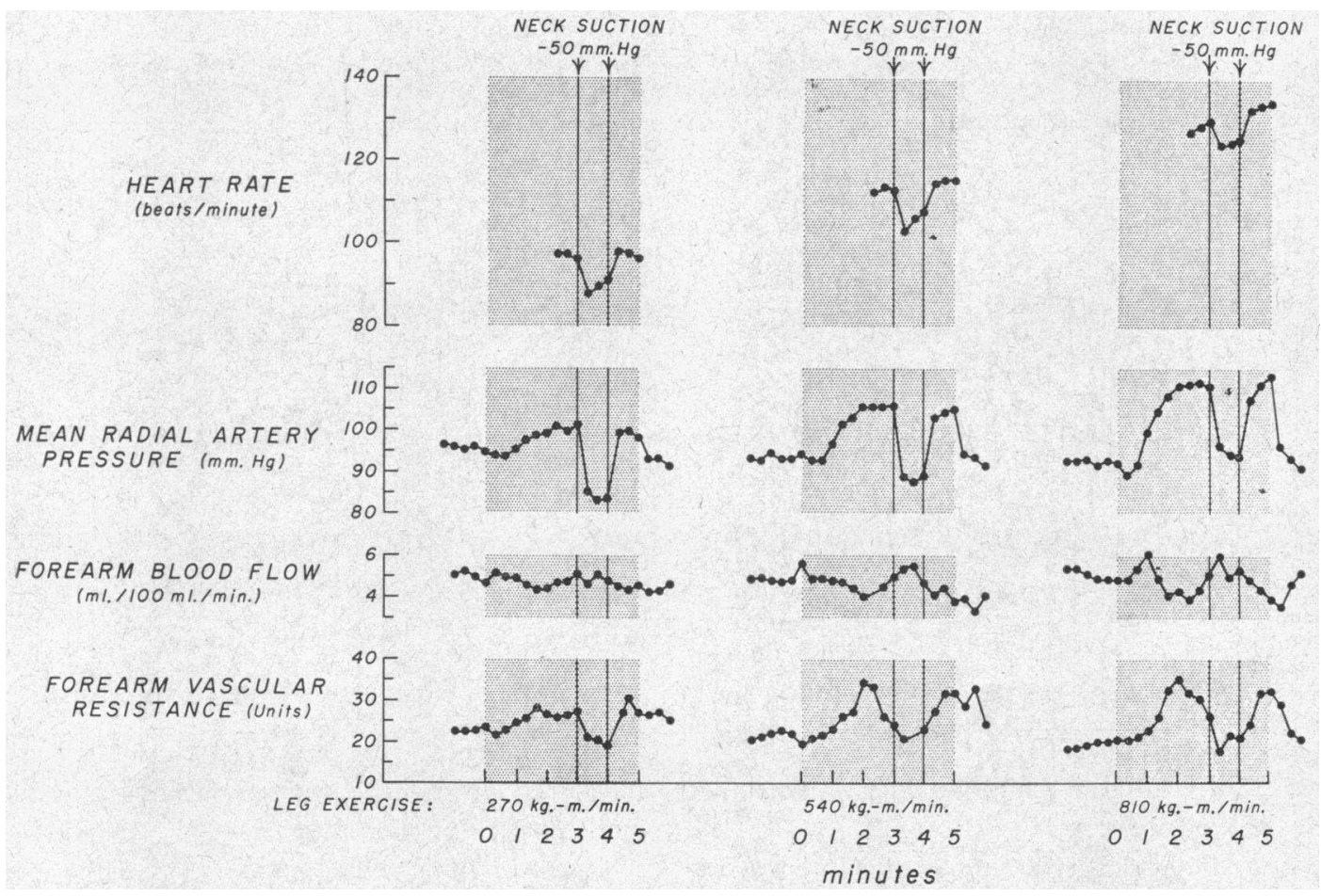

Fig. 6. EFFECTS OF NECK SUCTION DURING GRADED SUPINE LEG EXERCISE ON HEART RATE, MEAN RADIAL ARTERIAL PRESSURE, FOREARM BLOOD FLOW, AND FOREARM VASCULAR RESISTANCE. Average of six normal subjects.

cating active dilatation of forearm resistance vessels as a consequence of the increased transmural pressure at the carotid sinus. The venous pressure in a forearm with arrested circulation increased with leg exercise. This increase, which was graded to the severity of the exercise, was caused by a reflex venoconstriction mediated by the sympathetic nerves (10). Neck suction during exercise did not result in any decrease in venous pressure in the limb with arrested circulation.
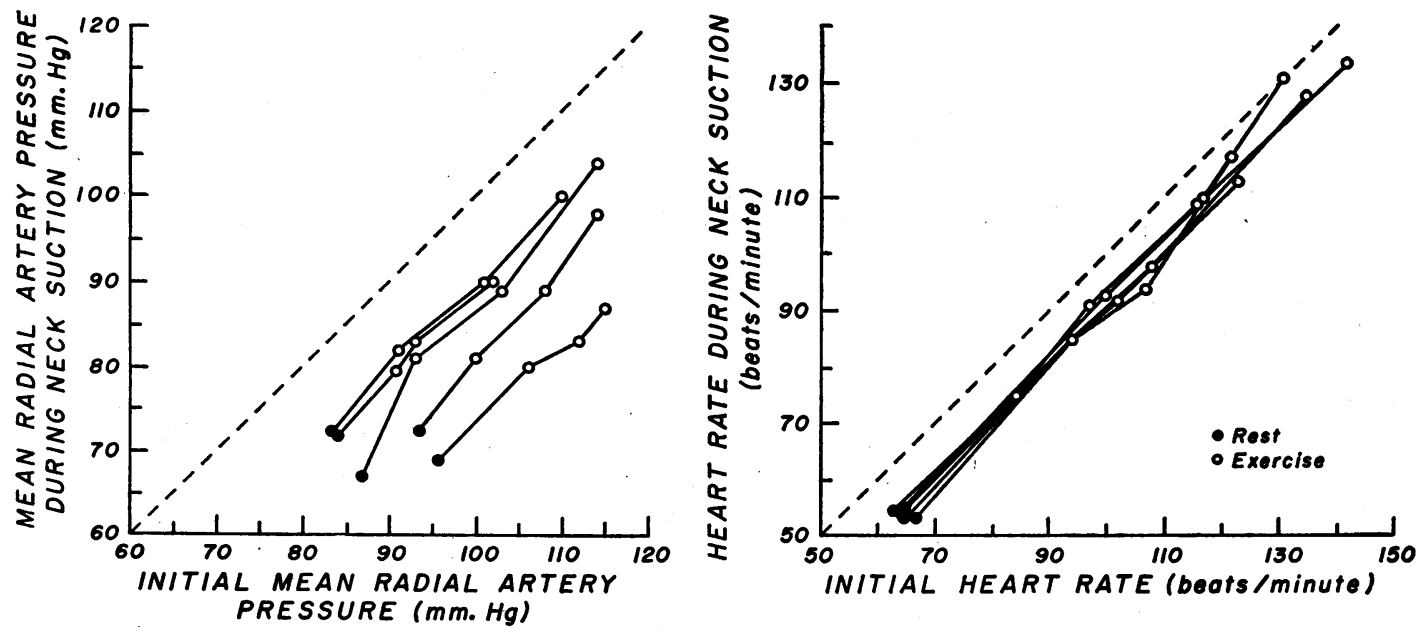

Fig. 7. Mean radial arterial pressure and heart RATE DURING NECK SUCtion EXPRESSEd AS FUNCTIONS OF THE VALUES OBTAINED WITHOUT SUCTION AT REST AND DURING GRADED SUPINE LEG EXERCISE IN FIVE NORMAL SUBJECTS. 
On the contrary, there was a small rise in pressure, indicating that a slight further increase in venous tone resulted from neck suction during exercise (Figure 5).

Cardiac output and stroke volume. During exercise the cardiac output increased with increasing work load with, on the average, small changes in stroke volume. During exercise the cardiac output decreased during neck suction in 13 of 15 determinations. The average decrease was $1.6 \mathrm{~L}$ per minute or $12 \%$. There was no significant difference in the response to neck suction among the three work loads; the decrease calculated from the total number of observations was significant $(p<0.01)$. The decrease was absolutely larger than at rest but was relatively of the same order. The stroke volume showed a variable response but on the average changed little. The calculated total peripheral vascular resistance, which decreases during exercise, was on the average unaffected by the stimulation of the carotid arterial stretch receptors.

\section{Discussion}

The subjects were healthy normal adults previously trained to perform the required exercise and well accustomed to the procedure and to the effect of the neck suction. They did not experience, subjectively or objectively, any emotional reaction to the tests. The introduction of catheters was made rapidly and without discomfort to the subjects. The resting values for pulse rate were at levels expected for resting, relaxed, nonathletic adults. Thus, the procedure, including the introduction of catheters, did not seem to change the condition of the subjects. The validity and limitations of the methods employed for evaluation of the reaction of resistance and capacity vessels have been discussed in other reports $(7,10,11)$.

With application of subatmospheric pressure around the neck, a certain proportion of this pressure will be transmitted into the tissues of the neck and to the walls of the vessels traversing the neck. Since the vessels constitute an open system when blood is flowing, the intravascular pressure immediately after application of subatmospheric pressure will be unchanged. Therefore, the pressure across the walls of both the veins and the arteries increases. Coles, Kidd, and Moffat (12) quote experiments in which the human calf was en- closed in a box, subjected to pressures of 20 to $100 \mathrm{~mm} \mathrm{Hg}$ below atmospheric, and the differential pressure measured between the tissues and the air in the box. It was found that the increases in transmural pressure were distributed throughout the leg tissues and were only slightly less than the level of subatmospheric pressure in any exposure. Although no such measurements have been made in the neck, it is likely that the findings would be similar. With the described design of the neck box, the transmural pressure increases not only at the carotid sinus but also along part of the common carotid arteries. This is advantageous, since the pressure receptors are not limited to the carotid sinus, but occur at several sites along the artery to the carotid sinus (2). When the depressor reflex on blood pressure is elicited, the pressure in the carotid arteries decreases. After a certain period of time, a steady state is reached when the initially high transmural pressure has reflexly decreased. At this time, however, the transmural pressure is greater than during the control period with ambient pressure in the box. Thus, the stimulus applied is, in principle, equal to raising the intravascular pressure of the carotid arteries. By means of the high capacity of the vacuum source, large-bore connections, good sealing of the box against the subject, and the manually controlled leak, the pressure in the box can be changed almost as a square wave. Since the strongest vacuum that could be tolerated with relative comfort by our subjects was $60 \mathrm{~mm} \mathrm{Hg}$ below ambient pressure, higher degrees of vacuum were not used. This degree of vacuum caused some sensation of stretch in the neck. The symptoms disappeared immediately when atmospheric pressure was restored in the box. Although the box was sealed against the thoracic aperture, the subatmospheric pressures were not transmitted into the thoracic cavity as judged by the absence of change in central venous pressure. A decrease in transmural pressure could be achieved by application of positive pressure to the box. This was not done, since, apart from technical difficulties in sealing with this reverse procedure, the ensuing venous congestion of the head makes this a less pure stimulus.

Effect at rest. When the pressure around the neck was lowered in steps, heart rate and blood pressure decreased almost linearly. Expressed 
as a percentage, the effect was more marked on blood pressure than on heart rate. Koch (13) related sinus pressure in dogs to percentage change in blood pressure and obtained S-shaped curves that were linear from the level of normal blood pressure and upward over a fairly wide range. In the present study on intact man, the percentage change in blood pressure was related to the calculated transmural pressure over the carotid artery during steady-state conditions. This relationship was also approximately linear over a fairly wide range of transmural pressures (Figure 3). Ernsting and Parry (3), who also stimulated the carotid arterial stretch receptors in man by subatmospheric pressure around the neck, found that the reflex bradycardia was transitory, whereas the blood pressure only partially recovered during the stimulus. They also found that cholinergic block with atropine abolished the heart rate response, but left the blood pressure response unaffected. This shows that the effect on the heart rate is mediated via cholinergic fibers and also supports the finding of Folkow and Uvnäs (14) that cholinergic sympathetic vasodilator fibers are not responsive to baroreceptor reflexes. In the present study, the subatmospheric pressure levels in the box were maintained constant during periods of 2 minutes, and the induced bradycardia was, on the average, maintained during this period. There were frequently an undershoot and overshoot in heart rate at onset and offset of neck suction. Also, the reduction in blood pressure was maintained and showed no tendency toward partial recovery. The results of the present study show that stimulation of the carotid arterial stretch receptors in man elicits marked sustained effects on heart rate and blood pressure; this suggests that there is little buffering effect from the other baroreceptor areas and that there is little or no adaptation during a 2-minute period. A gradual partial recovery in blood pressure, which has been said to be a characteristic feature of the response in animals, is ascribed to the buffering effect of remaining functioning baroreceptor areas (2). The effect on the heart rate was maximal by the second and third beats after onset of neck suction, whereas the blood pressure required 10 to 20 seconds to reach a plateau.

Concerning the effect of carotid sinus stimulation on cardiac output, in two observations on man,
Ernsting and Parry (3) found no change in the resting cardiac output during neck suction. Carlsten and associates (15), after stimulating the carotid sinus nerve in man and finding a decrease in arterial pulse pressure, suggested that this could indicate a decrease of the stroke volume due to venodilatation. In the present study in intact resting man, a small (10\%) but significant reduction in cardiac output with no significant change in stroke volume has been demonstrated during neck suction. Thus, the decrease in cardiac output followed the decrease in heart rate. However, a decrease in heart rate per se of the order of 10 to 15 beats per minute cannot be expected to cause a decrease in cardiac output, since it has been shown that changes in stroke volume compensate for variations in heart rate of this order (16). The small decrease in cardiac output may be due to a negative inotropic effect on the heart induced by increased transmural pressure over the carotid arteries. Recently, well-controlled animal experiments provided evidence for such a mechanism (17).

Since both cardiac output and mean arterial blood pressure decreased in the same proportion, the calculated total peripheral vascular resistance was, on the average, unchanged. However, in a situation in which perfusion pressure and flow change in the same direction, an unchanged ratio between these parameters does not allow undoubted conclusions to be drawn as to caliber changes in the resistance vessels. The studies on blood flow through the forearm in which the flow was not significantly changed during carotid sinus stimulation, although the perfusion pressure decreased, are indicative of an active dilatation of resistance vessels in the forearm. This agrees with the conclusions of Carlsten and associates (15), who found an increase in forearm blood flow when the carotid sinus nerve was stimulated in patients undergoing neck dissection. By contrast, Ernsting and Parry (3), who also stimulated the carotid arterial stretch receptors by applying subatmospheric pressure to the neck, found that there was no vasodilatation in the limbs to contribute to the decrease in arterial pressure. Roddie and Shepherd (18), who decreased the activity of the carotid sinus stretch receptors by compression of both common carotid arteries in man, concluded that there was no decrease in the caliber of the resist- 
ance vessels in the hand and calf to contribute to the rise in systemic pressure. Our study suggests that the decrease in systemic arterial pressure with carotid stimulation in resting subjects results from a slight decrease in cardiac output and some dilatation of resistance vessels. However, the reaction of vascular beds, other than the limbs, remains to be examined.

Effect during exercise. Stimulation during exercise also caused maintained reductions in heart rate and blood pressure. For a given stimulus, these reductions were absolutely the same at rest and during the three grades of exercise regardless of the initial levels of heart rate (at least up to 120 beats per minute) and blood pressure. In other words, heart rate and blood pressure during a standard stimulation are linearly related to the initial values of these parameters (Figure 7). This relationship also implies that the effect of stimulation, expressed as a percentage, decreases with increasing levels of heart rate and blood pressure. Therefore, although the carotid sinus mechanisms continue to oppose the increase in heart rate and blood pressure during exercise through negative feedback, the afferent stimuli responsible for the changes in heart rate and blood pressure with exercise are so strong that heart rate and blood pressure continue to increase in proportion to the severity of the exercise.

As in the resting subject, the decrease in systemic arterial blood pressure when the carotid sinus is stimulated during leg exercise is due to a combination of a modest decrease in cardiac output and an active dilatation of resistance vessels, at least in the inactive limbs. The decrease in output is likely to be caused by a direct negative inotropic effect on the heart for the same reasons discussed earlier. During leg exercise of the severity used in these experiments, the resistance vessels in the muscles of the resting forearm constrict to maintain the total blood flow through the forearm relatively constant in spite of the increasing perfusion pressure $(11,19)$. Against this background of reflex vasoconstriction, the reflex vasodilatation due to carotid sinus stimulation can be more convincingly demonstrated than in the absence of exercise.

With exercise, the limb veins constrict in proportion to the severity of the exercise, both in resting and exercising limbs $(10,11,20)$. The present study of the venous pressure changes in the forearm with completely arrested circulation provides no evidence that carotid sinus stimulation causes venodilatation even when venous tone is markedly increased during exercise. Conversely, some venoconstriction was elicited with the stronger degree of neck suction. This is contradictory to the general concept based on indirect evidence obtained from animal experiments that led Heymans and Neil (2) to postulate that effects on the venous system probably are the most important part of the carotid sinus reflex.

Since the reflex increase in tension of the smooth muscle of the venous system caused by exercise is probably important for the attainment and maintenance of the high cardiac output $(10,11)$, it would seem advantageous that this is not opposed via the carotid sinus mechanism as the systemic arterial pressure rises.

\section{Summary}

The carotid arterial stretch receptors have been stimulated in intact man by application of subatmospheric pressures to an airtight box enclosing the neck. The circulatory effects of stimulation were studied at rest and during graded supine leg exercise.

Increase of the transmural pressure of the carotid arteries in intact man results in maintained reductions in blood pressure and heart rate which, over a fairly wide range, are approximately linearly related to the stimulus. Percentagewise, the effect is smaller on heart rate than on blood pressure

A small (10 to $12 \%$ ) but significant reduction in cardiac output as well as a dilatation of resistance vessels in the limbs contributes to the decrease in arterial pressure both at rest and during graded exercise.

There is no evidence that carotid sinus stimulation causes venodilatation in the forearm of intact man either at rest or during exercise when venous tone is increased.

During exercise, stimulation of the carotid arterial stretch receptors causes reductions in heart rate and blood pressure of the same absolute magnitude as at rest regardless of the initial levels of arterial blood pressure and heart rate, at least with heart rates up to 120 beats per minute. 
Thus, the carotid sinus mechanism continues to oppose, through negative feedback, the rise in heart rate and blood pressure during exercise, but is overcome by the exercise stimulus so that the net result is an increase in both heart rate and blood pressure. The carotid sinus mechanism is less effective in opposing the increase in heart rate than in blood pressure.

\section{Acknowledgment}

We wish to thank Mr. Robert Lorenz for his cooperation, advice, and participation.

\section{References}

1. Hering, H. E. Die Karotissinusreflexe auf Herz und Gefässe vom normalphysiologischen, pathologischphysiologischen und klinischen Standpunkt (gleiczeitig über die Blutdrukzügler für den normalen und abnormen Kreislauf). Dresden, Theodore Steinkopff, 1927, vol. 6.

2. Heymans, C., and E. Neil. Reflexogenic Areas of the Cardiovascular System, Boston, Little, Brown, 1958.

3. Ernsting, J., and D. J. Parry. Some observations on the effects of stimulating the stretch receptors in the carotid artery of man (abstract). J. Physiol. (Lond.) 1957, 137, 45P.

4. Whitney, R. J. The measurement of volume changes in human limbs. J. Physiol. (Lond.) 1953, 121, 1.

5. Kerslake, D. McK. The effect of the application of an arterial occlusion cuff to the wrist on the blood flow in the human forearm. J. Physiol. (Lond.) 1949, 108, 451.

6. Wallace, J. M. Pressure relationships among arteries and large and small veins (abstract). Circulation 1956, 14, 1013.

7. Samueloff, S. L., B. S. Bevegård, and J. T. Shepherd. Temporary arrest of the circulation to a limb for the study of venomotor reactions in man. J. appl. Physiol. In press.

8. Fox, I. J., and E. H. Wood. Circulatory system: methods; blood flow measurement by dye-dilution technics in Medical Physics, Otto Glasser, Ed. Chicago, Year Book, 1960, vol. 3, pp. 155-163.

9. Snedecor, G. W. Statistical Methods Applied to Experiments in Agriculture and Biology, 5th ed. Ames, Iowa State College Press, 1956.

10. Bevegård, B. S., and J. T. Shepherd. Changes in tone of limb veins during supine exercise. J. appl. Physiol. 1965, 20, 1.

11. Bevegård, B. S., and J. T. Shepherd. Reaction in man of resistance and capacity vessels in forearm and hand to leg exercise. J. appl. Physiol. In press.

12. Coles, D. R., B. S. L. Kidd, and W. Moffat. Distensibility of blood vessels of the human calf determined by local application of subatmospheric pressures. J. appl. Physiol. 1957, 10, 461.

13. Koch, E. K. J. Die reflektorische Selbststeuerung des Kreislaufes. Dresden, Theodore Steinkopff, 1931, vol. 10.

14. Folkow, B., and B. Uvnäs. The distribution and functional significance of sympathetic vasodilators to the hind limbs of the cat. Acta physiol. scand. 1948, 15, 389.

15. Carlsten, A., B. Folkow, G. Grimby, C.-A. Hamberger, and $O$. Thulesius. Cardiovascular effects of direct stimulation of the carotid sinus nerve in man. Acta physiol. scand. 1958, 44, 138.

16. Ross, J., Jr., J. W. Linhart, and E. Braunwald. Effects of altering heart rate by electrical stimulation of the right atrium in man: studies at rest, during muscular exercise and isoproterenol infusion. Circulation. In press.

17. De Geest, H., M. N. Levy, and H. Zieske, Jr. Carotid sinus baroreceptor reflex effects upon myocardial contractility. Circulat. Res. 1964, 15, 327.

18. Roddie, I. C., and J. T. Shepherd. The effects of carotid artery compression in man with special reference to changes in vascular resistance in the limbs. J. Physiol. (Lond.) 1957, 139, 377.

19. Blair, D. A., W. E. Glover, and I. C. Roddie. Vasomotor responses in the human arm during leg exercise. Circulat. Res. 1961, 9, 264.

20. Bevegård, B. S., and J. T. Shepherd. Effect of local exercise of forearm muscles on forearm capacitance vessels. J. appl. Physiol. 1965, 20, 968. 